\title{
Population Mobility of Animal and Plant B-Chromosomes in Regions Subject to Technogenic Impact
}

\author{
Yuri M. Borisova* and Elena N. Muratova ${ }^{\text {b,c }}$ \\ ${ }^{a}$ A.N. Severtsov Institute of Ecology \\ and Evolution of the Russian Academy of Sciences, \\ 33 Leninsky Prospect, Moscow, 119071 Russia \\ ${ }^{b}$ V.N. Sukachev Institute of Forest of Siberian Branch \\ of the Russian Academy of Sciences, \\ Akademgorodok, Krasnoyarsk, 660036 Russia \\ ${ }^{c}$ Institute of Economy, Management and Use of Natural Resources \\ of the Siberian Federal University, \\ 79 Svobodny, Krasnoyarsk, 660041 Russia $^{1}$
}

Received 4.06.2010, received in revised form 11.06.2010, accepted 18.06.2010

The paper presents the studies on changes in number and morphology of B-chromosomes of field Apodemus peninsulae and spruce Picea obovata in Siberian populations subjected technogenic impact. For the first time the unique population of mouse Apodemus peninsulae which had numerous micro$B$-chromosomes (12-30), was found in Krasnoyark region. The mouse population inhabits a site at the left bank of the Yenisey river in $85 \mathrm{~km}$ downstream of the town of Zheleznogorsk where the Mining and Chemical Combine with chemonuclear complex is situated. The population of A. peninsulae from Gorny Altai showed threefold increase in number of B-chromosomes, from 2,3 to 7,1, during 28-year (1980-2008) studied period. The region of Gornyi Altai is the area where details of rockets launched from the Baikonur cosmodrome fall down. It was shown that the frequency of B-chromosomes of the Siberian spruce Picea obovata is higher in urban plantations (Krasnoyarsk city) than in its native populations. The effect of technogenic factors on acceleration of evolutionary processes is being discussed.

Keywords: B-chromosomes, karyotype, Korean field mouse Apodemus peninsulae, Siberian spruce Picea obovata, evolution, technogenic impact.

\section{Introduction}

Given the fact that there is an excess of DNA in the main stable part of A-chromosomes (normal chromosome set), it seems mysterious that 500 animal and 1300 plant species should have a variable part of B-genome represented by accessory, or B-chromosomes. The presence or absence of accessory chromosomes doesn't usually affect the phenotype - external appearance and other organism characteristics. Such correlation was only revealed in several species (Moshkovich, 1979; Jones, Rees, 1982;

\footnotetext{
* Corresponding author E-mail address: boris@sevin.ru (C) Siberian Federal University. All rights reserved
} 
Gileva, 2004). The functional significance of these supernumerary karyotype elements easily distinguishable from A-chromosomes has not been determined yet.

Recently a certain interconnection has been discovered between the heterochromatic regions of A- and B-chromosomes. They are filled with highly repetitious DNA sequences (Camacho et al., 2000; Karamysheva et al., 2002; Rubtsov et al., 2004). It was shown that B-chromosomes are formed by way of reorganization (duplication and amplification) of heterochromatic regions of A-chromosomes (Rubtsov et al., 2009). On the other hand, it is known that genome mobile elements generally move along the heterochromatic regions of chromosomes. The mobility of these regions, B-chromosomes and "jumping" genes might be the reasons of genome diversity leading to acceleration of its evolutionary transformations. In our opinion, the variable system of animal and plant B-chromosomes represents one of the karyotype's evolution paths.

The hypotheses that suggested earlier about the adaptive significance of B-chromosomes (Moshkovich, 1979; Jones, Rees, 1982) remain arguable to some extent; new facts are necessary to prove the involvement of B-chromosomes in the process of genome work regulation. Thus, it is of immediate interest to study B-chromosome mobility and connection of this phenomenon with technogenic impact. This paper shows the process of B-chromosome population mobility in regions subject to technogenic impact, illustrated by suitable ecological-evolutionary model objects such as the typical representatives of Siberian animal (Korean field mouse) and vegetable (Siberian spruce) kingdoms. Investigation of the natural complexes of Siberia is especially relevant taking into account the increasing commercial development of this region.
The Korean field mouse, Apodemus peninsulae (Thomas 1906), is a unique animal with regard to the number and mobility of its B-chromosomes (Hayata,1973; Bekasova et al., 1980; Radjabli, Borisov 1979; Kartavtseva et al., 2000; Borisov, Bochkarev, 2008; Borisov et al., 2010). This species demonstrates an unusual phenomenon: almost all specimens living in the vast habitat of the Eurasia's East-Asian part have from 1 to $30 \mathrm{~B}$-chromosomes in addition to 48 acrocentric A-chromosomes. This is the only mammal species that has various $\mathrm{B}$-chromosome morphotypes, from primary dot micro-Bchromosomes to macro-B-chromosomes comparable to the biggest A-chromosome. The largest range of B-chromosome number variability was detected in Siberian populations; Siberia is also the region where the greatest diversity of B-chromosome morphotypes is observed (Borisov et al., 2010).

The B-chromosomes of $A$. peninsulae populations in Siberia fall into five categories according to their size and morphology: from small dot micro-B-chromosomes to large biarmed macro-B-chromosomes (Borisov, 1990c). They form a system of various combinations of B-chromosome five classes. Small acrocentric B-chromosomes are observed less frequently. The meiosis prophase I of the Apodemus peninsulae clearly shows the differences in the structure of the axial elements and synaptonemal complexes of B-chromosomes belonging to different morphotypes (Borbiev et al., 1990; Kolomiets et al., 1988).

Morphometric measurements showed that the size of a B-chromosome system in one mouse can reach $29.7 \%$ of the length of its A-chromosome haploid set (Borisov, 1990b).

The Siberian spruce Picea obovata Ledeb., which is widely spread in the urban plantations of Siberia and often has accessory chromosomes, stands out against coniferous and other woody 
plants in terms of its karyotypic mobility (Muratova, Vladimirova, 2001; Vladimirova, 2002). B-chromosomes are often found in other representatives of Picea genus: they have been detected in 18 species and one interspecific hybrid (Muratova, 2000, 2009).

\section{Materials and methods}

The subjects of the study were 17 Korean field mice $A$. peninsulae caught on the left bank of Yenisey, in the village of Bereg-Taskino (Krasnoyarsk Territory), and 16 mice caught in the village of Artybash, on the northern shore of Lake Teletskoye (Republic of Gorny Altai). Live mice were caught using live traps in August. Chromosome spreads were made from bone marrow cells of the animals which had been colchicinated according to the generally accepted method (Rubtsov, 2006). Counting of chromosomes and registration of B-chromosomes at metaphases were carried out using the Leica D 5000 microscope. To describe the karyotype of each animal, 20 and more metaphase plates were used. To describe B-chromosomes, we used the formulas of 5 class digital coding according to their size and morphology (Borisov, 1990c).

For karyologic research of the Siberian spruce we selected 25 adult plants from the natural populations growing near Krasnoyarsk (Vodorazdel Platform and Kacha Station) and 40 trees from the Republic of Tyva (Khandagaity Village). In addition, 44 samples of adult plants were taken from the urban plantations in five areas of Krasnoyarsk: Large Concert Hall area, "Vzletka" bus terminal area, M. Gorky Central Park area, Youth Theatre area at Krasnoyarsky Rabochy Prospect, and Recreation Island area; as well as 8 ornamental trees from the arboretum of the Institute of Forest. All the studied plants had normal phenotype and were generally in good state. The material was young needles collected in spring. The research was carried out according to the generally accepted methods (Pravdin et al., 1972) using colchicination, fixation and staining with $1 \%$ acetohematoxylin. To make chromosome spreads, needles were put on an object-plate into a drop of chloral hydrate saturated solution; then $1.0-1.5 \mathrm{~mm}$ needle stems with meristematic cells were cut off, covered with a cover-glass and pressed. The spreads were examined with a MIB-6 microscope.

\section{Results and Discussion}

Population structure

and B-chromosome number

and morphotype dynamics of Korean field

mouse (A. peninsulae)

in regions subject to technogenic impact

A karyologic study of two spaced populations of Korean field mice (A. peninsulae) was carried out: population from the left bank of the Yenisey River in the village of Bereg-Taskino (Krasnoyarsk Territory), and population from the village of Artybash on the northern shore of Lake Teletskoye (Republic of Gorny Altai). The study of these two populations revealed significant differences in the population structure of B-chromosome system variants. All the 17 mice from the population of the left bank of Yenisey had from 12 to 30 micro-B-chromosomes and no macro-B-chromosomes. The Gorny Altai mice population where 16 specimen were studies mostly had both micro-B-chromosomes and macro-B-chromosomes (Tables 1 and 2).

The primary B-chromosomes are microB-chromosomes (Borisov, 1990c; Rubtsov et al., 2009). So far studies of more than $1000 \mathrm{~A}$. peninsulae mice from various areas of their habitat haven't revealed populations that would have only micro-B-chromosomes (Borisov et al., 2010). Micro-B-chromosomes were only found in individual specimens in populations living at the territories close to Krasnoyarsk. Examination of a population of $A$. peninsulae mice (17 specimens) 
Table 1. Variants of the micro-B-chromosome system in the population of Korean field mouse Apodemus peninsulae from Bereg-Taskino settl. on the left bank of the Enisey River (middle reach) (2008 - 2009)

\begin{tabular}{|c|c|c|c|}
\hline No. Ind. & Sex & Variants of the micro-B-chromosome system & $\begin{array}{c}\text { Number } \\
\text { of the B-chromosomes }\end{array}$ \\
\hline 1 & q & ............. & 12 \\
\hline 2 & $0^{\lambda}$ & ............ & 12 \\
\hline 3 & q & ............... & 14 \\
\hline 4 & $\hat{\sigma}$ & (............. & 14 \\
\hline 5 & $\widehat{0}$ & ................... & 16 \\
\hline 6 & 0 & ................... & 16 \\
\hline 7 & 0 & ................... & 18 \\
\hline 8 & 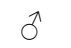 & ................ & 18 \\
\hline 9 & q & .................... & 20 \\
\hline 10 & 0 & ..................... & 20 \\
\hline 11 & q & ........................ & 22 \\
\hline 12 & $\hat{0}$ & ....................... & 22 \\
\hline 13 & q & ....................... & 24 \\
\hline 14 & 0 & $\ldots \ldots \ldots \ldots \ldots \ldots \ldots \ldots$ & 24 \\
\hline 15 & $0^{\pi}$ & .......................... & 26 \\
\hline 16 & q & n....................... & 26 \\
\hline \multirow[t]{2}{*}{17} & $\hat{0}$ & (n) & 30 \\
\hline & & Index of the B-chromosomes in 17 animals & 19,6 \\
\hline
\end{tabular}

from an area $180 \mathrm{~km}$ to the north of Krasnoyarsk showed that they have a large number (12-30) of micro-B-chromosomes. Table 1 shows the population structure of system variants in mice with 12-30 micro-B-chromosomes caught in the village of Bereg-Taskino. Fig. 1 illustrates the metaphase of an A. peninsulae mouse with 26 micro-B-chromosomes. Those mice included a specimen with $30 \mathrm{~B}$-chromosomes, which is a new maximal number for this species. Many micro-B-chromosomes were found in an $A$. peninsulae population from an area situated 85 $\mathrm{km}$ down the Yenisey stream, from the town of Zheleznogorsk where there is the Mining and Chemical Combine (GKhK) with chemonuclear complex. The effect of atomic reactor operation and GKhK radiochemical production on the animal and vegetable kingdoms is especially clearly seen in the flood plain and 50-m coastal belt of Yenisey (Bolsunovsky et al., 2007). As a result of radiation pollution of the Yenisey flood plain, the Korean field mice inhabiting the river banks might have an increased frequency of breaks in A-chromosome micro-reorganization hot spots. This will lead to more frequent formation of primary micro-B-chromosomes and formation of numerous micro-B-chromosomes (Rubtsov et al., 2009).

Individual specimens in each population have their own structure of B-chromosome system variants which is maintained for long periods of time (Borisov, 2008). In certain cases, under the constant influence of disturbing factors, the population balance of B-chromosome system variants can apparently be disrupted, and their number and morphotypes change. Such phenomenon of growing B-chromosome number accompanied by morphotype change has been observed for almost 30 years in the Gorny Altai population (in the village of Artybash on Lake 
Table 2. Numbers and morphotypes of the B-chromosomes in population of Apodemus peninsulae in the village of Artybash (Republic of Gorny Altai) in 1980 (Borisov, 1990a) and 2008

\begin{tabular}{|c|c|c|c|c|c|c|c|c|}
\hline \multirow{2}{*}{$\begin{array}{l}\text { No. } \\
\text { ind. }\end{array}$} & \multirow{2}{*}{ Sex } & \multirow{2}{*}{$\begin{array}{l}\text { Variants of } \\
\text { the B-chromosome system }\end{array}$} & \multirow{2}{*}{$\begin{array}{l}\text { Number } \\
\text { B-xp. }\end{array}$} & \multicolumn{5}{|c|}{ Morphotypes of B-chromosomes } \\
\hline & & & & $\mathbf{X}$ & $\mathbf{X}$ & $\mathrm{x}$ & $\wedge$ & . \\
\hline & & Artybash village, 1980 & & & & & & \\
\hline 1 & $\delta$ & $\mathbf{x}$ & 1 & 0 & 1 & 0 & 0 & 0 \\
\hline 2 & $\hat{0}$ & $\mathbf{X X}$ & 2 & 1 & 1 & 0 & 0 & 0 \\
\hline 3 & $\hat{\sigma}$ & $\mathbf{X X}$ & 2 & 0 & 2 & 0 & 0 & 0 \\
\hline 4 & $\sigma^{\lambda}$ & $\mathbf{X X}$ & 2 & 0 & 2 & 0 & 0 & 0 \\
\hline 5 & $\hat{\sigma}$ & $\mathbf{X X}$ & 2 & 0 & 2 & 0 & 0 & 0 \\
\hline 6 & $\hat{0}$ & $\mathbf{X X}$ & 2 & 0 & 2 & 0 & 0 & 0 \\
\hline 7 & $\hat{0}$ & $\mathbf{X}_{\mathrm{x}}$ & 2 & 0 & 1 & 1 & 0 & 0 \\
\hline 8 & q & $\mathbf{X X X}$ & 3 & 0 & 2 & 1 & 0 & 0 \\
\hline 9 & 우 & $\mathbf{X X X}$ & 3 & 0 & 3 & 0 & 0 & 0 \\
\hline \multirow[t]{3}{*}{10} & o & $\mathbf{X} \mathbf{X} \times \mathbf{X}$ & 4 & 2 & 2 & 0 & 0 & 0 \\
\hline & & $\begin{array}{l}\text { Index of the B-chromosomes in } \\
10 \text { animals }\end{array}$ & 2,3 & 0,3 & 1,8 & 0,2 & 0 & 0 \\
\hline & & Artybash villiage, 2008 & & & & & & \\
\hline 1 & o & $\mathbf{X} \mathbf{X}^{\wedge} \wedge$ & 4 & 0 & 2 & 1 & 1 & 0 \\
\hline 2 & $\sigma^{2}$ & $\mathbf{X} \times x^{\wedge}$ & 5 & 0 & 1 & 2 & 1 & 1 \\
\hline 3 & $\hat{o}$ & $\mathbf{X X X} \times \mathbf{x}$ & 6 & 2 & 1 & 2 & 0 & 1 \\
\hline 4 & $\sigma^{2}$ & $\mathbf{X} \times \mathbf{x} \times \ldots$ & 6 & 1 & 1 & 2 & 0 & 2 \\
\hline 5 & o & $\mathbf{X} \mathbf{X} \mathbf{X}_{\mathbf{x}}^{\wedge}$ & 6 & 1 & 2 & 1 & 1 & 1 \\
\hline 6 & $\hat{0}$ & $\mathbf{X} \mathbf{X} \times \mathbf{x x x}^{\wedge}$ & 7 & 2 & 1 & 3 & 1 & 0 \\
\hline 7 & $\hat{\sigma}$ & $\mathbf{X} \mathbf{X} \mathbf{X x x}^{\wedge}$ & 7 & 1 & 2 & 3 & 1 & 0 \\
\hline 8 & $\hat{0}$ & $\mathbf{X x x \times x ^ { \wedge }}$ & 7 & 0 & 1 & 4 & 1 & 1 \\
\hline 9 & 우 & $\mathbf{X} \mathbf{X}_{\mathrm{xx}^{\wedge} \wedge \wedge}$ & 7 & 0 & 2 & 2 & 2 & 1 \\
\hline 10 & q & $\mathbf{X} \mathbf{X X X X}_{\mathbf{x} \times{ }^{\wedge}}$ & 7 & 2 & 1 & 3 & 1 & 0 \\
\hline 11 & $\hat{\sigma}$ & $\mathbf{X}_{\mathrm{x} \times \mathrm{xxx}^{\wedge}}{ }^{\wedge}$ & 7 & 1 & 0 & 5 & 1 & 0 \\
\hline 12 & o & $\mathbf{X} \mathbf{X} \mathbf{X X X}_{\mathbf{x}} \wedge$. & 8 & 2 & 3 & 1 & 1 & 1 \\
\hline 13 & 우 & $\mathbf{X X X} \mathbf{X X} \times \mathbf{x}$. & 8 & 3 & 2 & 2 & 0 & 1 \\
\hline 14 & 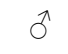 & $\mathbf{X} \times x_{x \times x} \wedge$ & 9 & 1 & 1 & 5 & 1 & 1 \\
\hline 15 & q & $\mathbf{X X X X _ { x x } { } ^ { \wedge } \ldots}$ & 10 & 3 & 1 & 2 & 1 & 3 \\
\hline \multirow[t]{2}{*}{16} & $\hat{\sigma}$ & 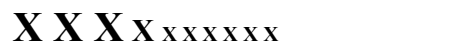 & 10 & 3 & 1 & 6 & 0 & 0 \\
\hline & & $\begin{array}{l}\text { Index of the B-chromosomes in } \\
16 \text { animals }\end{array}$ & 7,1 & 1,4 & 1,4 & 2,8 & 0,8 & 0,8 \\
\hline
\end{tabular}

Teletskoye). In this population a new genetic from Gorny Altai. Analyzing the state of this and evolutionary phenomenon was discovered: population in 2008, we found that the most genome mutations of B-chromosomes (Borisov, frequently occurring mice were mice with 2008).

Table 2 shows data on the B-chromosome number and morphotypes of $A$. peninsulae seven B-chromosomes, and two mice from that area had ten $\mathrm{B}$-chromosomes each. The average number of B-chromosomes was 7.1 


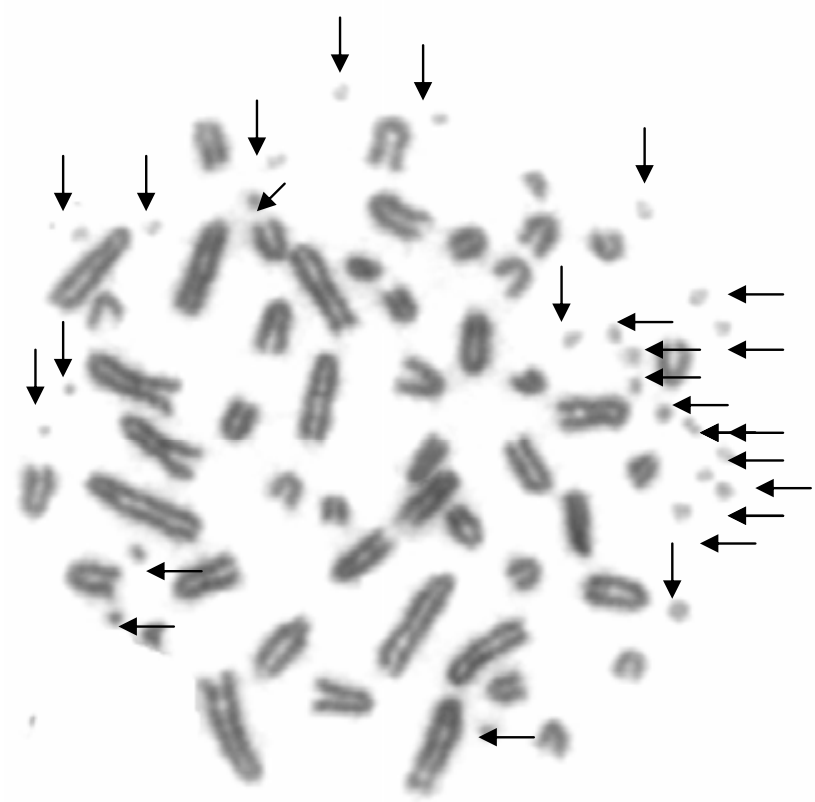

Fig. 1. Metaphase plate of the Korean field mouse Apodemus peninsulae with micro-B-chromosomes $(2 \mathrm{n}=48+26$ micro-B-chromosomes) from the population of Bereg-Taskino at the left bank of Yenisey. The B-chromosomes are shown with arrows

per specimen. The first study of this population was performed in 1980. In a sample of ten mice most of the specimens had two or three B-chromosomes, and the typical individual system variants of two mice contained three and four B-chromosomes. In the following years, the average number of B-chromosomes in the Gorny Altai population of $A$. peninsulae nearly tripled - from 2.3 to 6.5 in 2002 and 2006 (Borisov, 1990a, 2008), and to 7.1 in 2008. Along with macro-B-chromosomes, we found micro$\mathrm{B}$-chromosomes in this population in 2002 and 2006. It turned out that the growing number of B-chromosomes was accompanied by changes in their morphotypes. The number of macro-Bchromosomes grew until 2002. Then, in 2002, micro-B-chromosomes appeared in individual specimens, and they kept on growing in 2006 and 2008. As a result, in 2008 the number of macro-B-chromosomes decreased, and the number of micro-B-chromosomes increased, as compared to the year 2006 .
The analysis of events that could have possibly caused the population mobility of B-chromosome number and morphotypes gives grounds to suppose that their correlation can depend on the frequency of such elementary acts as A-chromosome breaks in hot spots and B-chromosome DNA amplification. Such breaks lead to formation of micro-B-chromosomes (Rubtsov et al., 2009). Moreover, when DNA repeats were localized using fluorescence in situ hybridization (FISH) it was found that microB-chromosomes are the derivative fragments of the near-centromere areas of A-chromosomes (Rubtsov et al., 2004). At the subsequent stages they are reorganized into macro-B-chromosomes. It must be noted that in each population a certain critical number of macro- and microB-chromosomes is maintained (Rubtsov et al., 2009).

The micro-B-chromosomes of $A$. peninsulae mice from Siberia revealed uncondensed DNA repeats that had been unknown before (Rubtsov 
et al., 2004). It is assumed that introduction of such repeats into micro-B-chromosomes can stop the process of their reorganization into macro-Bchromosomes typical for this species (Rubtsov et al., 2009). Obviously, in the studied population of mice from the left bank of Yenisey there is a constant process of micro-B-chromosome accumulation until they reach a critical number not exceeding 30, and then they are eliminated. Whether such population state of mice with micro-B-chromosomes is stable in this region subject to strong technogenic impact, remains an open question. Thus, it might be of interest to monitor mice populations from this region in future.

What factors can cause such reorganization of a genome within a short period of time? Quite possibly, these are the industrial factors of the region. It is well known that Gorny Altai has for a long time been subject to technogenic impact, including disposal of rocket stages. A total of 618 rocket stages each containing up to $800 \mathrm{~kg}$ of highly toxic fuel asymmetric dimethylhydrazine $(\mathrm{ADMH})$, or "heptyl", were thrown down to disposal area No 326 (partially covering the Altai State Reserve and bordering upon the studied territory) (Panin, Perova, 2006). "Heptyl" is a hazard class 1 toxic substance of rocket fuel. "Heptyl" derivatives tend to accumulate in vegetation cover which is the main nutritional resource of voles and mice.

Northern red-backed voles (Clethrionomus rutilus Pall.) from the areas surrounding the village of Artybash show clear evidence of pathologic processes in respiratory system and liver, and their haematological parameters are comparable to those of mice from the Chernobyl accident zone (Moskvitina et al., 2006). The experiments with rats showed that "heptyl" causes dystrophic damage in liver and immunodeficiency in newborn rats. It was stated that "heptyl" has the effect of a membrane- acting poison damaging erythrocyte membranes (Panin, Perova, 2006). Inhalation of ADMH at a concentration of $1028 \mathrm{mg} / \mathrm{m} 3$ (LD50 $=620 \mathrm{mg}$ ) $\mathrm{m} 3$ for rats) induces twice as many chromosome aberrations in bone marrow cells as in control (Kolumbaeva et al., 2007). The disposal areas to which spent rocket stages from Baikonur and Plesetsk spaceports were taken are situated near residential places which have recently seen an increase in oncological and chronic diseases (Ilyinskikh et al., 2003; Sidorov et al., 2006). Therefore, it is undoubtedly important to estimate the role of industrial factors in these processes.

The discovered phenomenon of mobile changes in B-chromosome number and morphotypes in one of the Gorny Altai populations of Korean field mouse during the studied period (1980-2008) allows for a new interpretation of their role in the microevolution of the species and confirms the importance of B-chromosomes for genome work. The ecological and evolutionary processes detected in the Gorny Altai population of mice are unique for this species. Repeated studies of dozens of other Korean field mouse populations (and continued 20-plus-year studies of certain populations) within their vast habitat haven't revealed any such phenomena in the dynamics of B-chromosomes (Borisov, 2008). Neither has such phenomenon been discovered in other animal and plant species with B-chromosomes.

\section{Population structure and B-chromosomes}

of the Siberian spruce (P. obovata)

at the territory of large industrial centers

The karyotype of the Siberian spruce P. obovata contains 24 A-chromosomes, eight pairs of which are long metacentric chromosomes, two pairs are short metacentric chromosomes, and two pairs are short submetacentric chromosomes. This species sometimes has accessory, or 
Table 3. B-chromosomes of Siberian spruce in natural populations and urban plantations

\begin{tabular}{|c|c|c|c|c|}
\hline \multirow{2}{*}{ Site } & \multirow{2}{*}{ Number of plants } & \multicolumn{3}{|c|}{ Chromosome number (2n) and its frequency } \\
\hline & & 24 & $24+1 B$ & $24+2 B$ \\
\hline \multicolumn{5}{|c|}{ Natural populations } \\
\hline \multicolumn{5}{|l|}{ Krasnoyarsk Territory, Vodorazdel } \\
\hline Platform & 25 & 25 & - & - \\
\hline Krasnoyarsk Territory, Kacha Station & 25 & 23 & 2 & - \\
\hline Tyva Republic, Khandagaity Village & 40 & 38 & 2 & - \\
\hline Total: & 96 & 86 & 4 & - \\
\hline \multicolumn{5}{|c|}{ Urban plantations of Krasnoyarsk city } \\
\hline IF SB RAS Arboretum & 8 & 5 & 2 & 1 \\
\hline Large Concert Hall area & 10 & 4 & 6 & - \\
\hline "Vzletka" bus terminal area & 6 & 3 & 3 & - \\
\hline M. Gorky Central Park area & 10 & 8 & 2 & - \\
\hline Youth Theatre area & 10 & 6 & 4 & - \\
\hline Recreation Island area & 8 & 4 & 3 & 1 \\
\hline Total: : & 52 & 30 & 20 & 2 \\
\hline
\end{tabular}

B-chromosomes; their number varies from one to four, and their size is approximately $20-30 \%$ of the average length of A-chromosomes. In terms of morphology, accessory chromosomes can be either metacentric $\left(B_{1}\right.$ type) or submetacentric ( $\mathrm{B}_{2}$ type).

This article presents the results of studying the adult trees of the Siberian spruce $(P$. obovata) from the natural populations around Krasnoyarsk and urban plantations of Krasnoyarsk. The 25 trees at the Vodorazdel Platform (60 km from Krasnoyarsk) didn't have accessory chromosomes. Two of the 25 trees from the Kacha Station $(50 \mathrm{~km}$ from Krasnoyarsk) population had metacentric B-chromosomes. Out of 40 studied trees in the Republic of Tyva (the village of Khandygayty, habitat southern border, near Mongolia) two trees had metacentric accessory chromosomes. Thus, only four out of a total of 90 trees growing in natural populations had B-chromosomes (Table 3).

Examination of the Siberian spruce urban plantations in Krasnoyarsk (areas of the Large
Concert Hall, "Vzletka" bus terminal, M. Gorky Central Park, Youth Theatre at Krasnoyarsky Rabochy Prospect, and Recreation Island) resulted in detection of accessory chromosomes in all the studied areas (Table 3). The trees in the areas of the Large Concert Hall, "Vzletka", Central Park and Youth Theatre had, along with typical A-chromosome sets, one metacentric B-chromosome. The karyotype of the Recreation Island spruce plantation contained one and two $\mathrm{B}_{1}$-type accessory chromosomes. The ornamental trees from the arboretum had B-chromosomes of both morphological types: meta- and submetacentric chromosomes. In total, B-chromosomes were found in the karyotypes of almost half of the studied trees from urban plantations $(42.3 \%)$ and in ornamental forms (56.2\%). B-chromosomes of the Siberian spruce are shown on Fig. 2.

As was previously stated after studying of the seed progeny obtained by open pollination, the two types $\left(\mathrm{B}_{1}\right.$ and $\left.\mathrm{B}_{2}\right)$ of $\mathrm{B}$-chromosomes are also found in other Siberian spruce natural populations in the central areas of Krasnoyarsk 


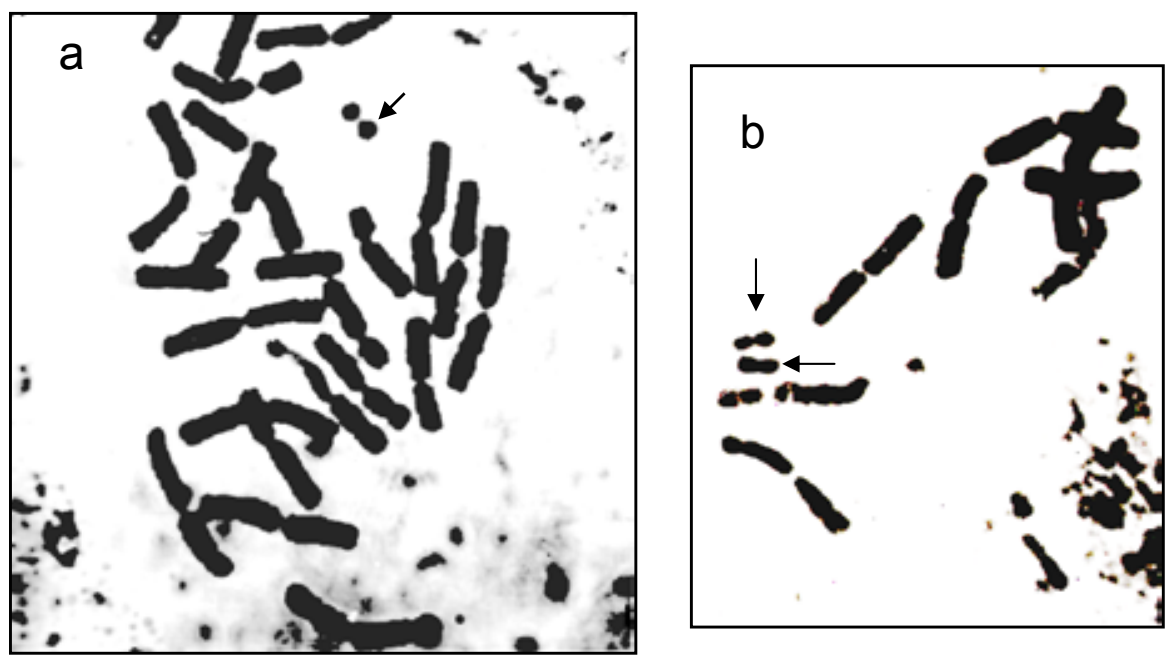

Fig. 2. Metaphase plates of the Siberian spruce (Picea obovata) from the populations of the Central and Southern Siberia with different number of B-chromosomes: $a$ - one B-chromosome $(2 n=24+1 B)$; $b$ - plate fragment with two B-chromosomes $(2 \mathrm{n}=24+2 \mathrm{~B})$. The B-chromosomes are shown with arrows

Territory (Muratova, Vladimirova, 2001; Vladimirova, 2002). An increased frequency of their occurrence was detected in the town of Chernogorsk (Republic of Khakassia), in plantations out of the habitat bounds, which is probably explained by the introduction conditions in the industrial center with developed coal mining. Thus, B-chromosomes are more often found in the urban plantations of the Siberian spruce than in its natural populations.

Similar data were obtained as a result of karyological study of the blue spruce $P$. glauca (Moench) Voss growing in the center of Voronezh. Eight out of ten trees had one B-chromosome. Two seedlings of the seed progeny of these trees had one to two B-chromosomes (Butorina, Bogdanova, 2001). It is quite possible that the appearance of B-chromosomes in trees growing in large industrial centers (Krasnoyarsk and Voronezh) is a result of A-chromosome mutations caused by aviation industry emissions and motor vehicle exhaust fumes.

In few cases accessory chromosomes were found in other coniferous trees. For example, one B-chromosome was found in a nursling of one of the common pine (Pinus sylvestris) trees growing at a forest-steppe area in Chelyabinsk Oblast, within the territory of the so-called "Ural radioactive trail". B-chromosomes supposedly appeared as a result of a mutation process; nurslings of other trees from that seed plot had chromosome mutations (Butorina et al., 1979). In the work of P.I. Molotkov et al. (1989) the common pine seeds were exposed to a chemical mutagen, N-nitrosomethylurea, after which a "witches' broom" type nursling was grown with a B-chromosome.

It is very rare that accessory chromosomes are found in certain Larix species; there is never more than one B-chromosome. It was in the Gmelin larch population growing at the habitat southern border that B-chromosomes were first discovered for this species (Muratova, 1994). Later B-chromosomes were found in several populations of the Sukachev larch in Southern Ural, in Bashkortostan, which is an environmentally neglected zone (Farukshina, Putenikhin, 2004), and in the Siberian larch samples from the areas surrounding the Far North cities and towns like Norilsk, Talnakh, 
and Kayerkan, exposed to sulphur emissions (Sedelnikova, Pimenov, 2007). B-chromosome was also found in the Siberian larch from the village of Tuim (Khakassia) where human-caused pollution is observed (Sizykh et al., 2006). When studying the Siberian larch plantations in the polluted districts of Krasnoyarsk and its environs we detected various types of chromosome aberrations (Muratova et al., 2008) which often accompany the appearance of B-chromosomes.

\section{Conclusion}

The research results demonstrate the necessity of further genetic monitoring of animal and plant populations with B-chromosomes in areas subject to technogenic and industrial impact. Studies in this direction will make it possible to work out a new B-chromosome marker test system for estimation of mutational variability trend on animal and plant objects exposed to technogenic impact.

Recently a significant acceleration of evolutionary rate has been revealed in a series of objects affected by industrial factors; especially illustrative are small mammals, rodents with a short lifespan who are good models for studying ecological and evolutionary processes. Studies of small mammals have a predictive impact on future generations of humans. Woody plants, on the contrary, have a late reproductive phase and grow on one place, which makes them suitable for long-term monitoring. In addition, they have a relatively small number of large chromosomes and easily identifiable B-chromosomes. In this connection using these objects for conducting the mentioned research appears to be promising.

\section{Acknowledgements}

The authors would like to acknowledge the help of the following research assistants and students of the SFU in expedition works: T.T. Lebedev, G.A. Sokolov, M.N. Senotrusova, and T.Yu. Ivanova. The work was supported by the RFBR grants No 08-04-00034a and 09-04-01390a, SB RAS integration project No 76, "Biodiversity" Basic Research Program of the RAS Presidium, "Gene Pools and Genetic Diversity" subprogram (23-П) and "Scientific and Pedagogical Manpower for Innovative Russia" Federal Target Program (2009-1.1-141063-021).

\section{References}

Bekasova T.S., Vorontsov N.N., Korobitsyna K.V., Korablev V.P. (1980) B-chromosomes and comparative karyology of the mice of the genus Apodemus. Genetica, 52-53 (1): 33-44.

Bolsunovsky A.Ya., Muratova E.N., Sukovaty A.G., Pimenov A.V., Sanzharaeva E.A., Zotina T.A., Sedelnikova T.S., Pankov E.V., Kornilova M.G. (2007) Radioecological monitoring of the Yenisei river and citological characterization of a submerged aquatic plant Elodea canadensis. Radiatsionnaya biologiya. Radioekologiya, 47 (1): 63-73.

Borbiev T.E., Kolomiets O.L., Borisov Yu.M., Safronova L.D., Bogdanov Yu.F. (1990) Synaptonemal complex of A-chromosome and B-chromosome in spermatocytes of the East-Asiatic mouse Apodemus peninsulae. Tsitologia, 32 (2): 193-196.

Borisov Yu.M. (1990a) Cytogenetic structure of Apodemus peninsulae (Rodentia, Muridae) population on the coast of Teletskoye lake (Altai). Russian J. of Genetics, 26 (7): 1212-1220.

Borisov Yu.M. (1990b) Variability Cytogenetic Structure of Apodemus peninsulae (Rodentia, Muridae) in West Sayans. Russian J. of Genetics, 26 (8): 1484-1491. 
Borisov Yu.M. (1990c) Cytogenetic differentiation of Apodemus peninsulae (Rodentia, Muridae) population in East Siberia. Russian J. of Genetics, 26 (10): 1828-1839.

Borisov Yu.M. (2008) Increase in the number of the B-chromosomes and variants of their system in mouse Apodemus peninsulae in Mountain Altai over 26 years. Russian J. of Genetics, 44 (9): 1070-1079.

Borisov Yu.M., Bochkarev M.N. (2008) Diversity and individuality of variants of the system of B chromosomes in mice Apodemus peninsulae. Russian J. of Genetics, 44 (12): 1438-1445.

Borisov Yu. M., Afanas'ev A.G., Lebedev T.T., Bochkarev M.N. (2010) Multiplicity of B microchromosomes in a Siberian population of mice Apodemus peninsulae ( $2 \mathrm{n}=48+4-30 \mathrm{~B}$-хромосом). Russian J. of Genetics, 46 (6): 705-711.

Butorina A.K., BogdanovaE. V.(2001) Adaptive significance and possible origin of B-chromosomes in Picea glauca (Moench.) Voss = P. canadensis B.S.P. Tsitologyia, 43 (8): 809-814.

Camacho J.P.M., Sharbel T. F., Beukeboon L.W. (2000) B-chromosome evolution. Phil. Trans. R.. Soc. Lond., 355 (1394): 163-178.

Farukshina G.G., Putenikhin V.P. (2004) Karyological analysis of Larix sukaczevii in the Urals. Russian J. Forest Science, 6: 25-33.

Gileva E.A. (2004) The B-chromosome system in the varying lemming Dicrostonyx torquatus Pall., 1779 from nature and laboratory populations. Russian J. of Genetics, 40 (12): 1399-1406.

Hayata I. (1973) Chromosomal polymorphism caused by supernumerary chromosomes in the field mouse, Apodemus giliacus. Chromosoma. 42 (4): 403-414.

Ilyinskikh N.N., Ilyinskikh E.N., Ilyinskikh I. N. (2003) Natural and antropogenous factors influencing on condition of health of Altai Republic population. Tomsk. $136 \mathrm{p}$.

Jones R.N., Rees H. (1982) B-chromosomes. London; N. Y.; Paris: Acad. Press, 266 pp.

Karamysheva T.V., Andreenkova O.V., Bochkaerev M.N., Borisov Y.M, Bogdanchikova N, Borodin P.M., Rubtsov N.B (2002) B chromosomes of Korean field mouse Apodemus peninsulae (Rodentia, Murinae) analysed by microdissection and FISH. Cytogenet Genome Res., 96: 154-160.

Kartavtseva I.V., Roslik G.V., Pavlenko M.V., Amachaeva E.Yu., Sawaguchi S., Obara Y. (2000) The B-chromosome system of the Korean field mouse Apodemus peninsulae in the Russian Far East. Chromosome Science. 4: 21-29.

Kolomiets O.L., Borbiev T.E., Safronova L.D., Borisov Yu.M., Bogdanov Yu.F. (1988). Synaptonemal complex analysis of B-chromosome behavior in meiotic prophase I in the East-Asiatic mouse Apodemus peninsulae (Muridae, Rodentia). Cytogenet. Cell Genet. 48 (3): 183-187.

Kolumbaeva S.Zh., Shalakhmetova T.M., Begimbetova D.A., Bersimbaev R.I., Kalimagambetov A.M.. (2007) Mutagenic effect of the rocket fuel component asymmetric dimethylhydrazine on rats of different age. Russian J. of Genetics, 43 (6): 608-612.

Molotkov P.I., Kirichenko O.I., Bengus Yu.V. (1989) On the origin of the Witche-Broom in Scotch pine. Tsitologia i Genetika, 23 (4): 14-19.

Moshkovich A. M. (1979) Supernumerary chromosomes of angiosperm plants. Kishinev: Shtiintsa, $163 \mathrm{p}$.

Moskvitina N.S., Kokhonov E.V., Paderov Yu.M. (2006) State of animal populations (Clethrionomys rutilus, Pall.) as demonstration of environment contamination of some regions of Altai mauntains. Population Ecology of Animals. Proc. of Int. Con. "Problems of population ecology of animals". Tomsk: 319-321. 
Muratova E.N. (1994) Chromosome polymorphism in the natural populations of Gmelin larch, Larix gmelinii (Rupr.) Rupr. Tsitologia i Genetika, 28 (4): 14-22.

Muratova E.N. (2000) B-chromosomes of Gymnosperms. Biology Bulletin Reviews, 120 (5): 452-465.

Muratova E.N., Vladimirova O.S. (2001) B-chromosomes in karyotype of Siberian spruce P. obovata. Cytologija i Genetika, 35 (4): 38-44.

Muratova E.N., Karpjuk T.V., Vladimirova O.S., Syzikh O.A., Kvitko O.V. (2008) Cytological studies of Siberian larch in anthropogenous disturbed regions of Krasnoyarsk and its environs. Vestnik of Ecology, Forest Science and Landscape Science, 9: 99-108.

Muratova E.N. (2009) Supernumerary chromosomes of woody plants. Karyology and Molecular Systematics. Proc. of VI conf. on Karyology, Karyosystematics and Molecular Phylogeny of Plants. Saint-Petersburg: 9-13.

Panin L.E., Perova A.Yu. (2006) Medico-social and environmental problems of use of liquidpropellent rockets (heptyl). Bulletin of the Siberian Branch, Russian Academy of Meducal Sciences, 119 (1): 124-131.

Pravdin L.F., Budaragin V.A., Kruklis M.V., Shershukova O.P. (1972) Methods of karyologic investigation of conifers. Russian Forest Sciences, 2: 67-75.

Radzhabli S.I., Borisov Yu.M. (1979) Variants of B-chromosome system in continent forms of Apodemus peninsulae (Rodentia, Muridae). Dokladi Akademii Nauk SSSR, 248 (4): 979-981.

Rubtsov N.B. (2006). Methods of works with mammalian chromosomes. Textbook. Novosibirsk. $147 \mathrm{pp}$.

Rubtsov N.B., Borisov Y.M., T.V. Karamysheva, M.N. Bochkarev (2009) Mechanisms of formation and evolution of the B-chromosomes in Korean field mouse Apodemus peninsulae (Mammalia, Rodentia). Russian J. of Genetics, 45 (4): 389-396.

Rubtsov N.B., T.V. Karamysheva, Andreenkova O.V., Bochkarev M.N.,Kartavtseva I.V., Roslik G.V., Borisov Y.M. (2004) Micro B chromosomes of Korean field mouse Apodemus peninsulae (Rodentia, Murinae): morphology, DNA contents, and evolution. Cytogenet. and Genome Research. 106 (2-4): 289-294.

Sedel'nikova T.S., Pimenov A.V. (2007) Chromosomal mutations in Siberian larch (Larix sibirica Ledeb.) on Taimyr peninsula. Biology Bulletin, 34 (2): 198-201.

Sidorov P.I., Sovershaeva S.L., Skrjabtsova N.B. (2006). Foundation of system monitoring on territory of influence of rockets and space activity. J. Human Ecology, 5: 12-16.

Syzikh O.A., Kvitko O.V., Muratova E.N., Tikhonova I.V. (2006) Variability of forms and karyotype features of Siberian larch (Larix sibirica Ledeb.) of Siberia south. Conifers of the boreal area, 23 (2): 202-211.

Vladimirova O.S. (2002) Karyological features of the Siberian spruce (Picea obovata Ledeb.) from different provenances. Tsitologia, 44 (7): 712-718. 


\title{
Популяционная мобильность В-хромосом животных
}

\author{
и растений в регионах, \\ подверженных техногенному воздействию
}

\author{
Ю.М. Борисов ${ }^{\mathbf{a}}$, Е.Н. Муратова ${ }^{\boldsymbol{\sigma}, \mathrm{B}}$ \\ а Учреждение Российской академии наук \\ Институт проблем экологии \\ и эволюиии им. А.Н. Севериова РАН, \\ Россия 119071, Москва, Ленинский пр., 33 \\ ${ }^{\sigma}$ Учреждение Российской академии наук \\ Институт леса СО РАН им. В.Н. Сукачева, \\ Россия 660036, Красноярск, Академгородок \\ ${ }^{6}$ Институт экономики, управления и природопользования \\ Сибирского федерального университета, \\ Россия 660041, Красноярск, пр. Свободный, 79
}

Представлены исследования изменения числа и морфологии В-хромосом мышей Ародети peninsulae и ели Picea obovata в популячиях Сибири, подверженных техногенному воздействию. В Красноярском крае впервые обнаружена уникальная популяция мышей A. peninsulae $c$ множеством микро-В-хромосом (12-30). Эта популяиия мышей обитает на левобережье реки Енисей в 85 км ниже по ее течению от г. Железногорска, где расположен Горно-химический комбинат с его ядерно-химическим производством. В популяиии мымей Apodeтиs peninsulae Горного Алтая за 28-х летний период исследований (1980-2008 г2.) обнаружено трехкратное увеличение числа В-хромосом (от 2,3 до 7,1). Регион Горного Алтая является местом падения вторых ступеней ракет, запускаемых с космодрома Байконур. Показано, что у Picea obovata частота встречаемости В-хромосом в городских насаждениях крупного промышленного центра (2. Красноярск) выше, чем в естественных природных популяииях этого вида. Обсуждается влияние техногенных факторов на ускорение эволючионных процессов.

Ключевые слова: кариотип, В-хромосомы, популячия, мышь Apodeтиs peninsulae, ель Picea obovata, техногенное влияние, процесс ускорения эволюции. 